\title{
The Problem Based Learning Model in Improving Concept Understanding and Self-Confidence Identification on Chemical Bonds at SMA Negeri 13 Pekanbaru
}

\author{
Helmy Hidayat ${ }^{1,2, *}$, Maria Erna ${ }^{2}$, Lenny Anwar $^{2}$ \\ ${ }^{1}$ Pondok Pesantren Al Ihsan Riau, Desa Kubang Jaya Kec Siak Hulu, Kampar, Riau, 28452, Indonesia \\ ${ }^{2}$ Chemistry Education, PMIPA, Universitas Riau, Pekanbaru 28293, Indonesia
}

\section{ARTICLE INFO}

\section{Article history:}

Received: 16 Nov 2020

Revised: 21 June 2021

Accepted: 27 June 2021

Published online: 24 July 2021

Keywords:

Chemical Bonding

Concept Understanding

Confidence

Problem Based Learning

\begin{abstract}
A B S T R A C T
This study aims to see the improvement of conceptual understanding and identification of students self-confidence by applying the Problem Based Learning (PBL) learning model to chemical bonding material. This type of research is quantitative with a pre-experimental design using the one group pretest-posttest step. The sample of this research was 36 students of Class X MIA 1 at SMA Negeri 13 Pekanbaru. Data collection techniques were using questionnaires and questionnaires. Quantitative descriptive data analysis technique was by calculating the percentage value of students' concept understanding. The results of data analysis showed that there was an increase in understanding of the concept of chemical bonds from 37.28 (pretest) to 81.39 (posttest), which was an increase of 44.11. The results of the analysis using the paired sample ttest with a significance value of $0.000<0.05$. The results of the identification of students self-confidence obtained 81.94 with a very good category. The application of the Problem Based Learning model can improve understanding of concepts and be able to raise the confidence of students.
\end{abstract}

\section{Introduction}

Improvement and improvement of the quality of education cannot be separated from various efforts. One of the government's efforts is to implement and develop a competency-based curriculum in 2004 and 2006 into a 2013 curriculum with three domains of competence, namely: knowledge, attitudes, and skills. The implementation phase of the 2013 curriculum focuses on active student activities through a scientific process with the aim that learning will not only create students who have knowledge competencies, but are also able to create students who are good in attitudes and skills (Istijabatun, 2008).

\footnotetext{
* Corresponding author.

E-mail: helmyhidayat82@gmail.com
} 
Not just in the classroom, but the current curriculum directs students to apply it in everyday life. The learning process must be changed from teacher centered to student centered, the method which was originally dominated by expository has changed to participatory and the approach which was originally more textual has turned into contextual with a balance of knowledge, skills, and attitudes. In accordance with the revised 2013 curriculum, students are required to be able to interact, argue, debate, and collaborate so that the function of the teacher from the teacher changes by itself to become a facilitator for students in the teaching and learning process in the classroom. That the teaching and learning process is a complex phenomenon, everything means. Every word, thought, action and association and the extent to which the teacher changes the environment, presentation and teaching design (Depoter, 2007).

Chemistry lessons are a branch of the Natural Sciences (IPA) group which prioritizes a positive attitude, understanding concepts and developing students' problem-solving skills. The objectives in chemistry lessons can be achieved if all components involved in the learning process are actively involved and mutually support one another. Teachers play a very important role in the success of students in the learning process, both from the results of learning values and understanding concepts and the emergence of students' self-confidence (Rusminiati, 2015)

The main difficulty is that students can only repeat the definitions of terms in chemical bonding material, but do not really understand the real meaning, or it can be said that students have not been able to apply the concept of chemical bonds and tend to still rely on memorization. Over the past two decades, many researchers have found that students lack a deep understanding of the concept of chemical bonds and fail to integrate mental models into a coherent conceptual framework (Rusminiati, 2015). If students' understanding of a concept is not in accordance with the understanding of experts, it can be said that students have misconceptions or misconceptions. This concept error causes students' learning difficulties, so that the learning outcomes obtained are low (Istijabatun, 2008).

One of the learning models that integrates with the problem is the Problem Based Learning (PBL) model. Learning with the PBL model provides opportunities for students to construct their knowledge through investigating a problem and their personal ideas and concepts which then include one of the doctrines of pragmatism. One of his important contributions was to educational theory, as was his contribution to the philosophical tradition and his dexterity in maintaining a pragmatic orientation towards skills and their application to human life (Wasitohadi, 2014). This is reinforced by research on the PBL model that was conducted by Wasonowati (2014) which states that the application of the PBL model can have a positive impact on the activities and learning outcomes of students.

Furthermore, according to Kusdemir (2013) states that problem-based learning has a positive impact on students, which has an impact on increasing student learning achievement. Likewise, Zheng (2013) and Lidyawati (2017) state that the application of PBL in learning can make it easier for students to solve problems 
that arise during the learning process. According to Astika (2013) also states that using the PBL model can improve students' scientific attitudes and critical thinking skills. Furthermore, Qianli (2008) states that the PBL model can encourage students to solve a problem so that it can produce logical conclusions. Based on the background that has been stated above, the formulation of the problem in this study is how to apply the Problem Based Learning Model to improve conceptual understanding and confidence in chemical bonding learning materials at SMA Negeri 13 Pekanbaru.

\section{Methodology}

This research refers to a quantitative research approach. This type of research is a pre-experimental design and was developed using the steps of one group pretestposttest design (Syahrum and Salim, 2012). The sample of this research is the students of class X MIA 1 SMAN 13 Pekanbaru as the experimental class totaling 36 people. Data collection techniques using questionnaires. For the variable understanding of the group concept, a pre-test was given at the beginning before treatment by giving pretest questions as many as 25 questions with 4 chemical bond learning materials, namely: elemental stability and ionic bonds, covalent bonds, polar and non-polar covalent bonds and coordination covalent bonds. . This type of question uses two tire multiplechoice.

The self-confidence identification variable using a questionnaire consists of 20 statements with five indicators, namely: Believing in one's own abilities, Acting independently in making decisions, Respecting oneself and one's own efforts, Enthusiastic when expressing opinions during discussions, Dare to face challenges using a Likert scale. The results of the questionnaire are scored and in the form of a checklist $(\sqrt{ })$. Each question item consists of a question and the answer column has 5 alternative choices, namely Very Often (SS), Often (S), Sometimes (KK), Rarely (Jr), and Never (TP). This analysis was carried out by involving one sample class using the One Group Pretest-Posttest Design model. Implementation of the pretest to measure the dependent variable implementation of the treatment or experiment. The implementation of the posttest to measure the results or impact on the dependent variable using the independent sample t-test.

\section{Results and Discussion}

\section{Concept Understanding}

Concept understanding is one aspect of chemistry assessment that aims to determine the competence or ability of students to accept and understand the basic concepts of chemistry. Testing the results of understanding this concept is carried out based on the results of the pretest and posttest that have been done. The data test is carried out if the data normality test has been carried out. The results of the normality test are normally distributed, it can be seen in table 1 
Table 1. Normality Test

\begin{tabular}{lcccccc}
\hline & \multicolumn{2}{c}{ Kolmogorov-Smirnov $^{\mathbf{a}}$} & \multicolumn{3}{c}{ Shapiro-Wilk } \\
\cline { 2 - 7 } & Statistic & df & Sig. & Statistic & df & Sig. \\
\hline pre-test &, 164 & 36 &, 016 &, 934 & 36 &, 033 \\
Post-test &, 074 & 36 &, $200^{*}$ &, 973 & 36 &, 521 \\
\hline
\end{tabular}

Based on table 1, it can be seen that the two data have a sig count $>$ so it can be concluded that the pretest and posttest data are normally distributed at a significant level $(\alpha=0.05)$.

Table 2. Pre-test scores

\begin{tabular}{cccccc}
\hline Value pre-test & $\mathbf{F i}$ & $\mathbf{X i}$ & $\mathbf{X i}^{\mathbf{2}}$ & $\mathbf{F i X i}$ & $\mathbf{F i X i}^{\mathbf{2}}$ \\
\hline $20-29$ & 11 & 24,5 & 600,25 & 269,5 & 6602,75 \\
$30-39$ & 11 & 34,5 & 1190,25 & 379,5 & 13092,75 \\
$40-49$ & 6 & 44,5 & 1980,25 & 267 & 11881,5 \\
$50-59$ & 7 & 54,5 & 2970,25 & 381,5 & 20791,75 \\
$60-69$ & 1 & 64,5 & 4160,25 & 64,5 & 4160,25 \\
\hline Total & $\mathrm{n}=36$ & 222,5 & 10901,25 & 1362 & 56529 \\
\hline
\end{tabular}

Based on table 2, the minimum pretest score is 20 while the maximum score is 64 . The average pretest score is 37.28 . The category of low pretest scores is 4 people (scores 20-25), the category of moderate scores is 24 (scores 26-49) and the category of high scores is 8 people (scores $>50$ ). Then proceed with the posttest analysis process as set out in table 3 below.

Table 3. Post-test scores

\begin{tabular}{cccccc}
\hline Value post-test & $\mathbf{F i}$ & $\mathbf{X i}$ & $\mathbf{X i}^{\mathbf{2}}$ & $\mathbf{F i X i}$ & $\mathbf{F i X i}^{\mathbf{2}}$ \\
\hline $60-69$ & 3 & 64,5 & 4160,25 & 193,5 & 12480,75 \\
$70-79$ & 12 & 74,5 & 5550,25 & 894 & 66603 \\
$80-89$ & 14 & 84,5 & 7140,25 & 1183 & 99963,5 \\
$90-99$ & 7 & 94,5 & 8930,25 & 661,5 & 62511,75 \\
\hline Total & $\mathrm{n}=36$ & 318 & 25781 & 2932 & 241559 \\
\hline
\end{tabular}

Based on table 3, the minimum posttest score is 60 while the maximum value is 96. The average pretest score is 81.39 . The category of low posttest scores is 3 people (score $<70$ ), the category of medium value is 28 people (scores 70-90) and the category of high scores is 5 people (value $>90$ ). The next stage, the researcher conducted a paired sample $\mathrm{T}$ test aimed to determine the average difference between two groups of paired samples. The test results can be seen in table 4 .

Table 4. Test of paired samples t-test

\begin{tabular}{|c|c|c|c|c|c|c|c|c|c|}
\hline & & \multicolumn{5}{|c|}{ Paired Differences } & \multirow{3}{*}{$\mathbf{t}$} & \multirow{3}{*}{ df } & \multirow{3}{*}{$\begin{array}{c}\text { Sig. (2- } \\
\text { tailed) }\end{array}$} \\
\hline & & \multirow[t]{2}{*}{ Mean } & \multirow{2}{*}{$\begin{array}{c}\text { Std. } \\
\text { Deviati } \\
\text { on }\end{array}$} & \multirow{2}{*}{$\begin{array}{c}\text { Std. } \\
\text { Error } \\
\text { Mean }\end{array}$} & \multicolumn{2}{|c|}{$\begin{array}{c}95 \% \text { Confident } \\
\text { interval }\end{array}$} & & & \\
\hline & & & & & Lower & Upper & & & \\
\hline Pair 1 & $\begin{array}{l}\text { Pretest- } \\
\text { Postest }\end{array}$ & $-44,1111$ & 12,8547 & 2,1424 & $\begin{array}{l}- \\
48,4605\end{array}$ & 39,7616 & $-\overline{20,58}$ & 35 & ,000 \\
\hline
\end{tabular}


The test results obtained an increase in the average pretest and posttest of 44.11 with a sig of 0.000 . This means that the value of sig $<0.05$ indicates a significant increase in the results of understanding the concepts of students. The Mean result table is obtained from the results of the average difference between the pretest and posttest of -44.11. A negative value means that there has been an increase in the average value from pretest to posttest. The next stage of analysis is to look for differences in variation between groups (between groups) and variations within groups (within groups). The process is carried out using the one-way Anova test as shown in table 5 below.

Table 5. One Way Anova Test

\begin{tabular}{cccccc}
\hline & sum of squares & df & mean square & F & Sig. \\
\hline Between Groups & 35024,222 & 1 & 35024,222 & 320,912 &, 000 \\
Within Groups & 7639,778 & 70 & 109,140 & & \\
\hline \multicolumn{1}{c}{ Total } & 42664,000 & 71 & & & \\
\hline
\end{tabular}

Based on table 5, it can be seen that the average value in the between group is greater than within the group. This means that the intervention has a different effect, in other words, the mean value compared shows a significant difference (sig < 0.05). Based on the results of understanding the concept, there are four learning materials as indicators of the success of the learning model, namely: elemental stability and ionic bonds, covalent bonds, polar and non-polar covalent bonds and coordinating covalent bonds. The results of the frequency distribution can be seen in graph 1 below.

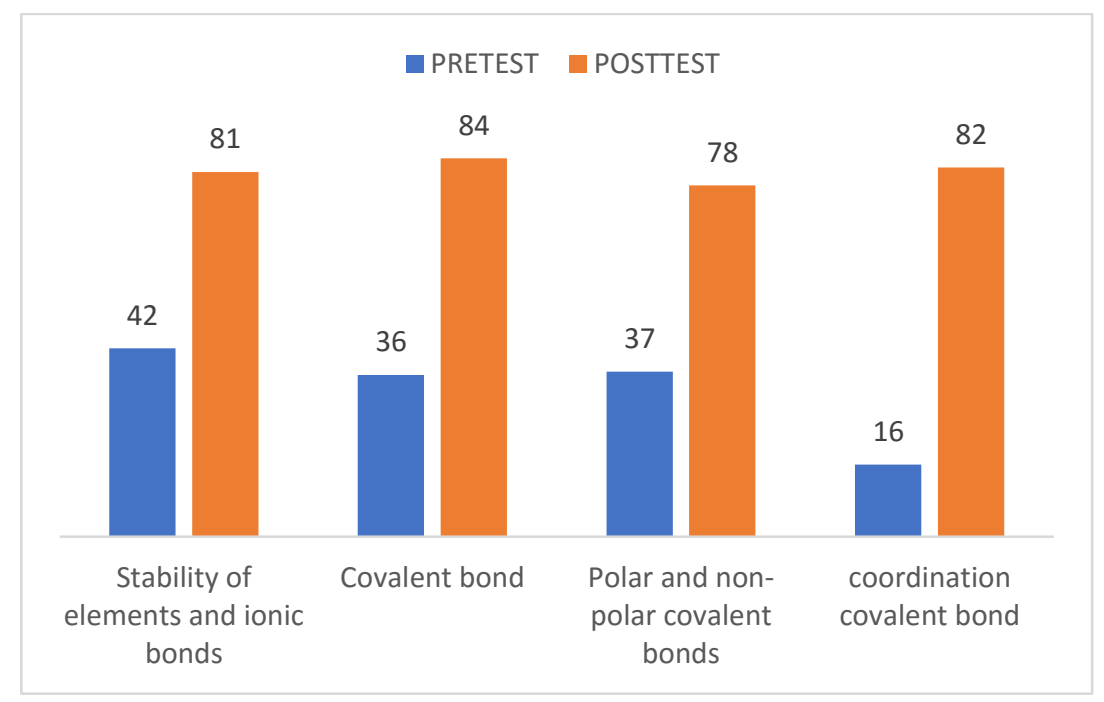

Figure 1. Comparison of Pre-test and Post-test scores on the Application of Problem Based Learning Model

Based on graph 1 there is a significant difference between the pre-test and posttest scores on each indicator of learning material. In the matter of elemental stability and ionic bonds there was an increase of 39 , the value of covalent bonds increased by 48 , the value of polar and non-polar covalent bonds increased by 41 
while the value of coordination covalent bonds showed the most significant increase in value of 66 .

This study is in line with the results of research conducted by Jahro and Ridho (2015) on the implementation of PBL in Hydrocarbon material which was carried out in both experimental classes with pretest and posttest treatments. This PBL model is said to be effective because it is a teaching model characterized by real problems as a context for students to learn critical thinking and problem solving skills and gain knowledge (Lidyawati, 2017).

Nelli's research (2016) explains that students also give good responses to the implementation of the PBL model, so it can be concluded that learning with the PBL model can improve student learning outcomes and scientific attitudes. When reviewed, the application of the PBL model is considered very effective in improving the quality of student learning. According to Hesson and Shed (2007) to improve the quality of students, teachers must implement an effective teaching process, by choosing the right method for each lesson material. The selection of various variations of teaching methods must be in accordance with the needs and characteristics of students. Kusdemir (2013) states that problem-based learning has a positive impact on students, which has an impact on increasing student learning achievement. The application of PBL in learning can make it easier for students to solve problems that arise during the learning process (Zheng, 2013)

The low quality of learning in Indonesia can be seen from one of the ranking indicators of Indonesia's Human Development Index, which includes the ranking of educational attainment at 124 out of 183 countries in the world. In addition, the media used to develop android-based chemistry learning media is more optimal in improving students' cognitive achievement (Lubis and Ikhsan, 2015)

\section{Confidence}

Self-confidence is a person's belief and attitude towards his ability in himself by accepting it as it is, both positive and negative, which are formed and learned. In this study, the measurement of the self-confidence identification value was carried out using a questionnaire. The form of the questionnaire is in the form of 20 statements with a Likert scale. There are five indicators of self-confidence, namely: believing in one's own abilities, acting independently in making decisions, respecting oneself and one's own efforts, being enthusiastic when expressing opinions during discussions and daring to face challenges. Each indicator has 4 statements. In the confidence indicator there are five indicators, there are 4 very good indicators (81-100) and 1 good indicator (61-80) with an average value of 81.94 (very good category). This means that the Problem Based Learning model is considered to be able to raise the confidence of students.

The results of this study indicate that the identification of the confidence level of students about chemical bonds gives a very good average value with a value of 81.94 after receiving treatment with the application of this PBL model. The research is in line with the research results of Handayani et al (2015) which say 
that improving student attitudes in learning with the PBL model is better. The follow-up to the educational foundation is the emergence of an orientation to the formation of competencies that are relevant to the demands of the real world. Competence includes knowledge, skills, values and attitudes possessed and can be displayed in professional performance.

\section{Conclusion}

The application of the Problem Based Learning Model can improve conceptual understanding and self-identification of students in the very good category on chemical bonding material in Class X MIA 1 SMA Negeri 13 Pekanbaru. The test results obtained an increase in the average pretest and posttest of 44.11 with a sig of 0.000 . This means that the value of sig $<0.05$ indicates a significant increase in the results of understanding the concepts of students. Meanwhile, for students' self-confidence, it shows that of the five indicators, there are four indicators with a very good category (81-100) and 1 good category indicator (61-80), with an average value of 81.94 (very good category). This means that the Problem Based Learning model is considered to be able to raise the confidence of students.

\section{Acknowledgment}

The author would like to thank the Master of Chemistry Education Study Program, FKIP, Riau University, the Principal and the teachers of SMA Negeri 13 Pekanbaru, who have provided many contributions and directions during the research process.

\section{References}

Astika, I. K. U., Suma. I. K., \& Suastra, I. W. (2013). Pengaruh Model Pembelajaran Berbasis Masalah terhadap Sikap Ilmiah dan Keterampilan Berpikir Kritis. E-Journal Program Pascasarjana Universitas Pendidikan Ganesha Program Studi IPA. 3(1), 1-10.

Depoter, B. (2007). Quantum Teaching. Mempraktikkan Quantum Learning di Ruang-ruang Kelas. Bandung: Raifa.

Handayani, T, I. D. A. T., Karyasa, I.W., Suardana. I. N (2015). Komparasi Peningkatan Pemahaman Konsep dan Sikap Ilmiah Siswa SMA yang Dibelajarkan Dengan Model Pembelajaran Problem Based Learning dan Project Based Learning. e-Jurnal Program Pascasarjana Universitas Pendidikan Ganesha Program Studi Pendidikan IPA. 5(1), 1-12.

Hesson, M \& K. F. Shad (2007). A Student-Centered Learning Model. American Journal of Applied Sciences. 4(9), 628-636.

Istijabatun, S. (2008). Pengaruh Pengetahuan Alam Terhadap Pemahaman Mata Pelajaran Kimia. Jurnal Inovasi Pendidikan Kimia, 2(2), 323-329.

Jahro I. S., \& Ridho. D. (2015) Penerapan Model Problem Based Learning Menggunakan Media Exe Learning untuk Meningkatkan Hasil Belajar dan 
Kerjasama Siswa Pada Materi Hidrokarbon. Jurnal Pendidikan Kimia (JPKIM) 7(3),80-86.

Kusdemir, M., A.Y. Yusuf \& C. Tuysuz. (2013). An Analysis of the Effect of Problem Based Learning Model on the 10th Grade Students' Achievement, Attitude, and Motivation in the Unit of "Mixtures". Journal of Science and Mathematics Education. 7(2),159-224.

Lidyawati, G. A., \& Khaldun, I. (2017). Penerapan Model Problem Based Learning Untuk Meningkatkan Hasil Belajar Dan Keterampilan Berpikir Kritis Peserta Didik Pada Materi Larutan Penyangga. Jurnal Pendidikan Sains Indonesia, 5(1), 140-146.

Lubis, I. R., \& Ikhsan. J. (2015). Pengembangan Media Pembelajaran Kimia Berbasis Android Untuk Meningkatkan Motivasi Belajar Dan Prestasi Kognitif Peserta Didik SMA. Jurnal Inovasi Pendidikan IPA 1(2), 191 201.

Nelli, E., Gani. A \& Marlina. (2016) Implementasi model Problem Based Learning pada Materi Kelarutan Dan Hasil Kali Kelarutan Untuk Meningkatkan Hasil Belajar dan Sikap Ilmiah Peserta Didik kelas XI SMA Negeri 1 Peudada. Jurnal Pendidikan Sains Indonesia, 4(2), 12-23,

Qianli, T. (2008). The Feasibility of Applying PBL Teaching Method to Surgery Teaching of Chinese Medicine. Journal International Education Studies. 1(4), 110-113.

Rusminiati, N.N., I. Karyasa, W, \& Suardana, I. N. (2015). Komparasi Peningkatan Pemahaman Konsep Kimia Dan Keterampilan Berpikir Kritis Siswa Antara Yang Dibelajarkan Dengan Model Pembelajaran Project Based Learning Dan Discovery Learning. $e$ - Journal Program Pascasarjana Universitas Pendidikan Ganesha Program Studi Pendidikan IPA. 5(1), 1-11.

Syahrum \& Salim (2012). Metode Penelitian Kuantitatif. Bandung: Cita Pustaka Media.

Wasitohadi. (2014). Hakekat Pendidikan Dalam Perspektif John Dewey Tinjauan Teoritis. Jurnal Satya Widya. 3(1), 49-61.

Wasonowati, R. R. T., Redjeki, T \& Ariani, S.R.D. (2014). Penerapan Model Problem Based Learning (PBL) pada Pembelajaran Hukum- Hukum Dasar Kimia Ditinjau dari Aktivitas dan Hasil Belajar Siswa Kelas X IPA SMA Negeri 2 Surakarta Tahun Pelajaran 2013/2014. Jurnal Pendidikan Kimia. 3(3), 66-75.

Zheng, Y. (2013). The Motivation of Problem-Based Teaching and Learning in Translation. Journal of Science and Education. 6(4),120-125.

How to cite this article:

Hidayat, H., Erna, M., \& Anwar, L. (2021). The Problem Based Learning Model Improves Concept Understanding and Self-Confidence Identification on Chemical Bonds at SMA Negeri 13 Pekanbaru. Journal of Educational Sciences, 5(3), 409-416. 